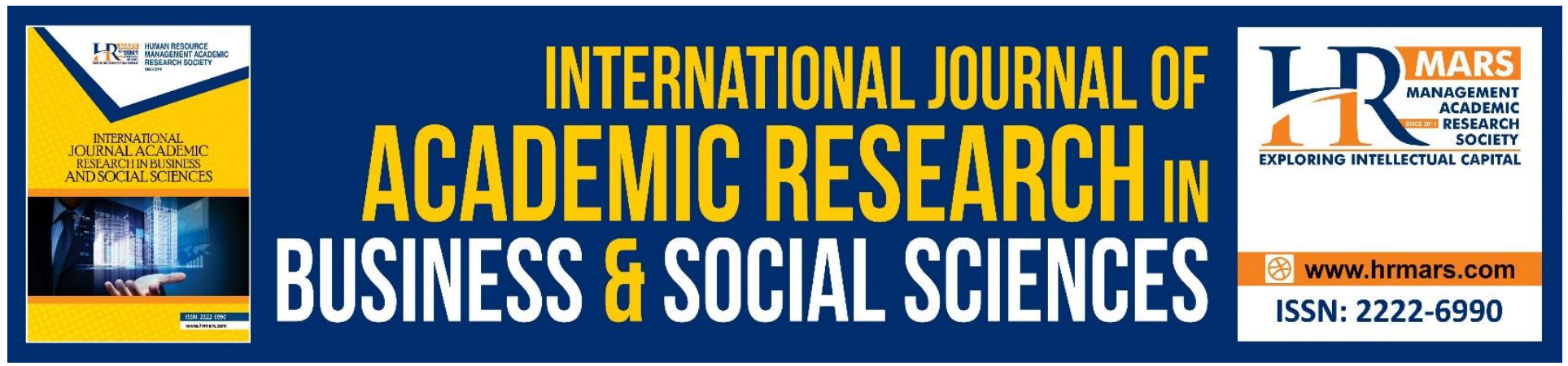

\title{
How Italian can Copycat from China by using Social Media APPs in Movie Marketing
}

\section{Giacomo Conti, Li Min}

To Link this Article: http://dx.doi.org/10.6007/IJARBSS/v8-i10/4766

DOI: $10.6007 /$ IJARBSS/v8-i10/4766

Received: 13 Sept 2018, Revised: 19 Oct 2018, Accepted: 26 Oct 2018

Published Online: 30 October 2018

In-Text Citation: (Conti \& Min, 2018)

To Cite this Article: Conti, G., \& Min, L. (2018). How Italian can Copycat from China by using Social Media APPs in Movie Marketing. International Journal of Academic Research in Business and Social Sciences, 8(10), 595605.

Copyright: (C) 2018 The Author(s)

Published by Human Resource Management Academic Research Society (www.hrmars.com)

This article is published under the Creative Commons Attribution (CC BY 4.0) license. Anyone may reproduce, distribute, translate and create derivative works of this article (for both commercial and non-commercial purposes), subject to full attribution to the original publication and authors. The full terms of this license may be seen

at: http://creativecommons.org/licences/by/4.0/legalcode

Vol. 8, No. 10, 2018, Pg. 595 - 605

http://hrmars.com/index.php/pages/detail/IJARBSS

JOURNAL HOMEPAGE

Full Terms \& Conditions of access and use can be found at http://hrmars.com/index.php/pages/detail/publication-ethics 


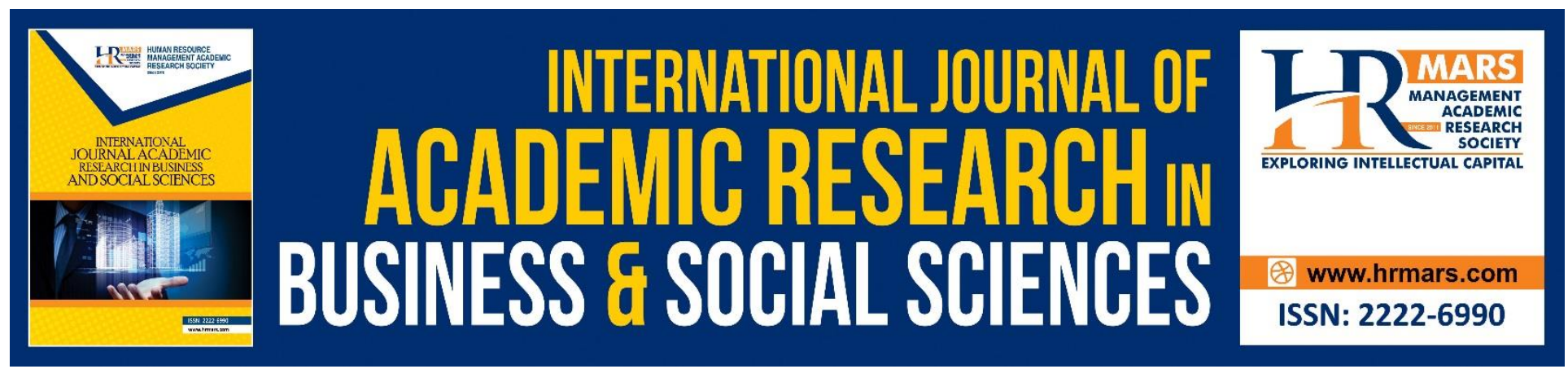

\section{How Italian can Copycat from China by using Social Media APPs in Movie Marketing}

\section{Giacomo Conti}

College of Economics and Management, Nanjing University of Aeronautics and Astronautics,

Nanjing 210016, China

Email: yuning16@icloud.com

\section{Li Min}

School of Economics and Management, Nanjing University of Aeronautics and Astronautics Associate professor, Doctor of Management, research area: movie marketing

Email : lingxao666@126.com

\section{Abstract}

The importance of social media and movie tickets sales are increasing nowadays thanks also to the large use of the Smartphone in everyday life. These new technologies have been widely used to many extents and especially into Chinese film industry. The purpose of this paper is to study their use in the Chinese movie market through the analysis of MaoYan. Thanks to social media and sort of Apps many research have been conducted to illustrate the modern trends but the lack of studies on this topic is a key motivation to further studies. The result demonstrates how clear is the importance for movie studios and Italy to implement more focus and attention on this new technology due to its facility and possibility to get data about movie trend at the cinemas.

Keywords: MaoYan, Movie Tickets, Smartphone, Social Media

\section{Introduction}

The movies and the investments involved in its production are increasing every year among many countries and especially in China (Barn, 2009). Many times the investors consider first the feasibility and after the profitability of a complex project like this. Not only the story or the plot must be assessed but also the cast, directors and technical aspects must be considered as important as the previous. More and more often due to the competitiveness of this market not all the movies are able to recover and have a decent surplus over their expenses (Wasko, 1982). So it's mandatory for almost every financier to evaluate carefully every facet of this industry and do not leave anyone behind. This is even more true in a period like this, where from one side the public and its tastes are changing and on the other side these attitudes and trends could be followed on the social media. 
This new technology is as useful as misleading if not well or badly interpreted for its data. Especially for this market where in general we only hear about the hit or blockbusters but the percentage of failure is pretty higher than of the success, the social media values and data always give good indications to the pre-launch of a movie but not a very high percentage of accuracy due to the evolving of the interests by the netizens (Shim, 2011).The importance of these online communities is fundamental for the improvement of success percentage of a released movie. Especially in Italy where the ticket sale system has remained unchanged for a long time a new system could give back vigor to this market. In fact, in this country the queue at the cinema is still present even if the population is significantly lower than that in China. The unique way to attract more customers is from personal insights like the $5 €$ ticket on special days or hours or special discounts linked to purchasing some products at the mall or at the fast food chains. Besides these rare occasions in general the moviegoers are not so encouraged and facilitated in purchasing the movie ticket. Rest of the paper sis organized as follows section explain literature and background, section three contain methodology, chapter four explain results section while section five concludes (Everett, 2009).

\section{Literature Review}

Many have studied the relationship between the WOM and the new eWOM that circulates on the internet. It is demonstrated how the judgments of people on the web deeply influence others. Furthermore many have examined how the social media are integrated in the European and North American citizens. First of all it was studied that the vast majority of users on the social networking websites belongs to demographic of young people. Mainly because they are part of the future population it is interesting study this group that will influence the box office in the following years. Due to this new technology the information travels faster than before and many social media websites can also instantly inform their users. In other words, if a good word of mouth is necessary for the success of a movie, it is now achievable through the use of this new technologies avoiding so very expensive marketing events(DeBauche, 2009) .

Many low budget movies have successfully used these tools and achieved excellent results at the box office without spending money on marketing campaigns. Even if the traditional campaigns are far more expensive respect to the social media ones is it clear that many efforts must be put in order to reach a good result at the box office (Zhao, 2017). So many for example have tried to predict the movie box office in first four weeks through the analysis of the Hollywood Stock Exchange, a market where the gross income and the ratio between it and the budget are predicted. In their study they were able to have an accuracy of the $80 \%$ which is very high in this market but due to the not so wide quantity of data they couldn't reach higher percentages. They also examined with the same approach the possibility to predict the box office of and the nominations of movies just by analyzing the volume of discussion in the IMdb forum and finding they are in a positive relation (The Association of European Vehicle Logistics, 2014). Forecasting the outcomes and revenues of a future released movie was a subject of research also by They analyzed two of the most popular social media, YouTube and Twitter that are ranked as $2^{\text {nd }}$ and $11^{\text {th }}$ respectively in the Alexa.com, a website that shares information about the Internet and webs traffic, have a total of almost two and half billions active users every month. Analyzing billions of comments and reviews 
made by users in these socials they found that they are also positively correlated to the trending at the box office of the 'talk-about' movies. Added to this, (Chambers, 2006)have analyzed the biggest social media (Facebook) in the world with a total amount of monthly active users of 2.2 billions. The issue of their consideration was the power of the 'like' button as a measure of prediction of the box office when the movie will be released finding also in this case that it has a positive influence.

The tools available through the social media are also studied in more modern and developing country like India and its Bollywood market. Exactly Nanda et al. have studied the marketing strategies adopted by the movie 'Queen' in three different socials, YouTube, Facebook and Twitter which were wisely used in the pre release period. But they found that the post release promotional and eWOM were on the same level of importance as the period preceding the release. Anyway as mentioned in the previous studies also in this market the influence of social media on the revenues and general appreciation of the movie was remarkable.

A similar situation was the research made by Taegu Kim et al. when forecasting the box office in the Korean market. They found that the positive and negative reviews in the social media were also a decisive factor to the success and the box office of the post-release period but the limitation of considering just the Korean movies.

Further to these, the Chinese market, which is growing fastly and attracting so the attention of foreign investors, was taken into consideration by many studies. Jooyoung Kwak \& Liyue Zhang have demonstrated how this market is determinant in the success of many foreign films in the 2007-2009 period. In fact they found that when a Chinese element, could be an actor, content, setting or others, is introduced into the foreign film the revenues of it are strictly and positively related. This participation is seen as 'friendly' and encourages and stimulates many times the Chinese viewers. But without a doubt, also in a developing country like China, the technologies are making giant steps. First the use of social media is increasing, e.g. Sina Weibo a Chinese microblogging website was just launched in the 2009 and has by now more than 411 million monthly active users, while YouKu a website that hosts millions of video with more than 500 million regular active users. Jia Xiao et al. have examined these two socials and found that they undoubtedly have a role in determining the final box office of a movie even if with the limitations of dynamicity of these websites that are related to the unpredictable and varying crowd's trends. However the presence of many social network sites could mislead the analysis so in this study only one new system that includes social media features will be considered (Dickinson \& Harvey, 2005).

\section{Methodology}

This study has a quantitative approach in its analysis. An online questionnaire has been used to analyze the trends in usage among a group of people. Using principally a "snowball effect" inviting so friends to share and help in the answering process the questionnaire has mainly focused on the opinion of users while purchasing a movie ticket in Italy. The background of examiners are prevalently students with $58 \%$ and working $35 \%$ while the remaining $7 \%$ is doing both work and study. Added to this a regression analysis and percentage method will be adopted in order to analyze the data (Obiaya, 2013) and (Dickinson \& Harvey, 2005). 
INTERNATIONAL JOURNAL OF ACADEMIC RESEARCH IN BUSINESS AND SOCIAL SCIENCES Vol. 8, No. 10, Oct. 2018, E-ISSN: 2222-6990 @ 2018 HRMARS

\section{Results}

The social media APP that allow sales of movie tickets.

A complementary tech to the social media are the smartphones that have created a new unique way of connecting people with many messaging and social media APPs on it. From a study (Sargent \& Hanewinkel, 2015)it was found that people spend 161.95 minutes on average every day and explaining how nowadays this new technology is part of our lives. This usage has also negative effects on students, in fact their academic results and efforts are influenced negatively and so cannot be overlooked. Moreover, the presence of many APPs in the smartphone world has evolved and enhanced the system of movie tickets' sale. From the social APPs like for example Twitter David Zimbra et al. have found that the Android users influence more the movie revenues through the posted tweets before its release while the iOS users are more active and followed on the post release period. Furthermore they also found how the advertisements by the movie industries are relatively efficient especially in the Android part. On the same advise are (Teti, 2013)where they support the idea that among youngers Malaysians the purchase rate of movie tickets is highly increased with the use of mobile advertisements. Various researchers used similar methodologies in other fields such as (Mohsin et al., 2018) and (Mohsin et al., 2018)

It is so clear that all over the world many studies have been conducted to examine and find the best way to forecast and predict the box office. While these good results have the potential in its market and have analyzed directly the clues and signals of future movies hits in different countries their weakness is their lack of study of new modern technologies like the Apps available in smartphones that allow the consumer to purchase the movie tickets directly on their device. This is what Mao Yan or 'The Cat's Eye' permit nowadays to Chinese citizens to do. Not only purchase but also interact with other users, reviewing a movie, liking it, expressing its own feeling and expectations months before its release and more. (Denby, 2012) This APP is born on the 2010 and by that year has seen a lot of improvements and attention by its developers leading to be the first shareholder of Chinese movie ticket market. The purpose of this study is so to analyze and consider this feature and to further implement and encourage others to take into exam this valid element. Just to give a brief introduction of this new system and to justify its employment it is useful to take a look at the following diagram (Orlov \& Ozhegov, 2015).

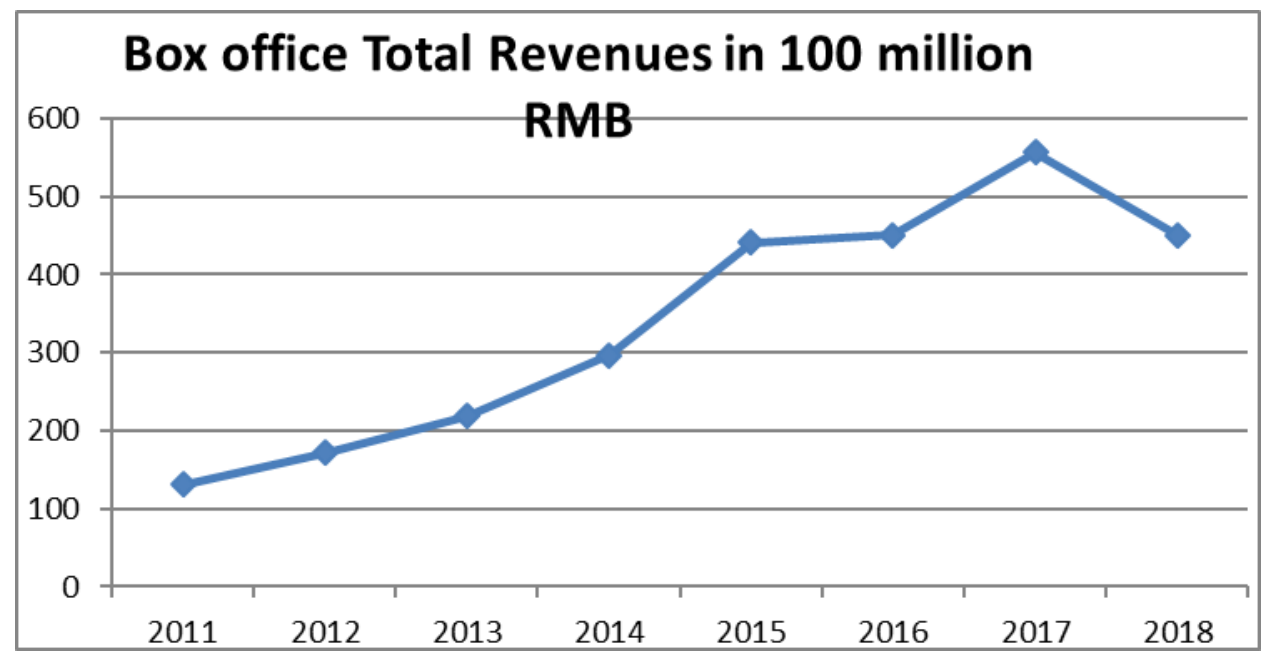


Fig. 1 Box office of China from 2011

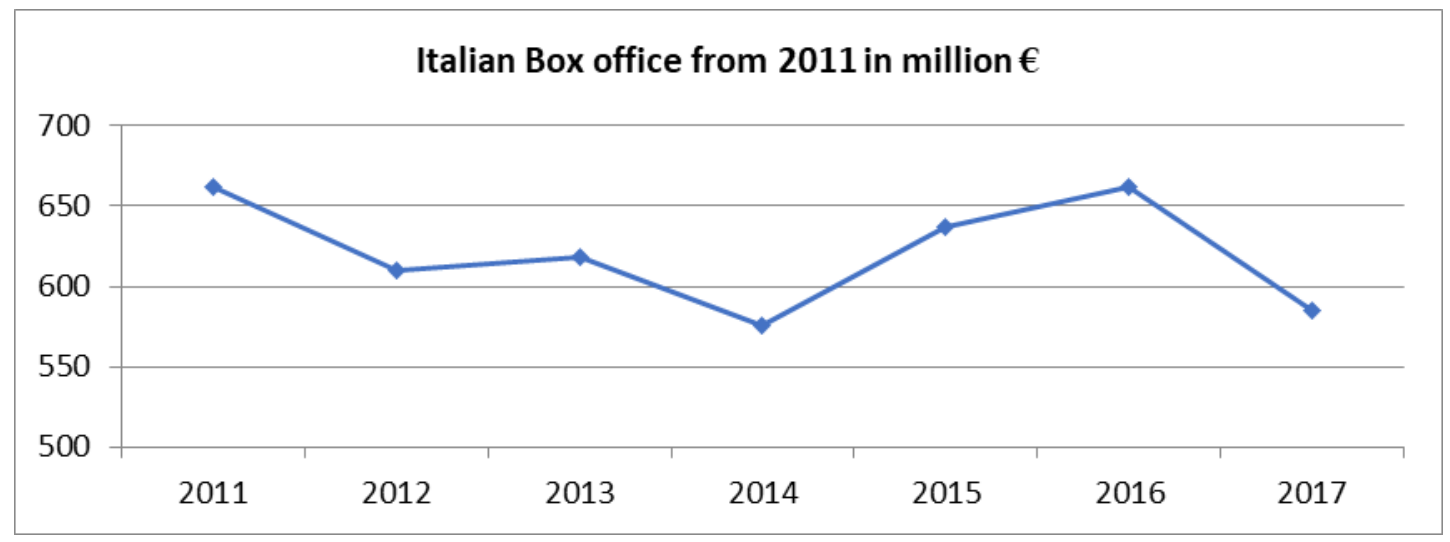

Fig. 2 Box office of Italy from 2011

The 2011 year was chosen in order to compare the different paths in the two nations with the respective introduction of this new tool in China and remaining to the same sale method in Italy. It's clear so that while in China we could see a boost in the selling of movie tickets with an always positive trend, in Italy the same market has faced frequent ups and downs. It is mandatory so to analyze the opinion of the public which is very important to understand the limits and possible solution to this problem. (Dreyer, 1970).

After collecting the data and answers from the people I have concluded this result.

Demographics of respondents

\begin{tabular}{|c|c|c|c|}
\hline & & Frequency & Percentage \\
\hline \multirow[t]{2}{*}{ Gender } & Male & 20 & $46 \%$ \\
\hline & Female & 26 & \\
\hline \multirow[t]{4}{*}{ Age } & & $\leq 18$ & 7 \\
\hline & & $18-25$ & 23 \\
\hline & & $26-35$ & 11 \\
\hline & & $\geq 36$ & 5 \\
\hline
\end{tabular}

$\begin{array}{cr}\text { Educational Background College or below } & 3 \\ \text { Bachelors } & 36 \\ \text { Masters or above } & 7\end{array}$

Smartphone Experience $\leq 2$ years 2

$3-4$ years $\quad 12$

$\geq 5$ years $\quad 32$

Frequency of daily $\quad 1$ h or below 8

Smartphone use $\quad 1-2 \mathrm{~h} \quad 25$

$2 \mathrm{~h}$ above $\quad 13$ 
Fig. 3 Demographic of respondents

In Fig. 1 we have found many details about the demographic of the respondents. First of all the gender of the sample is pretty balanced between male and female. Added to this the age of the respondents is well representing and in tuning with the other studies. The main body of this sample is in fact the young ones corresponding to students and new workers with a higher education background representing also how many Italians are trusting the academic courses. Beside this, the usage of smartphone is predominant over many other things and also it is one of the first and last things people do at bed. Moreover the hours spent on this gadget are many considered that people have to sleep and work at least 8 hours per day having so only 8 hours of "free time". The first questions were about the last movie seen at the cinema:

\begin{tabular}{|l|r|r|r|}
\hline & Frequency & Percent & \multicolumn{2}{|l|}{ Cumulative } \\
& & & \\
& & 13,0 & 13,0 \\
Partner & 6 & 58,7 & 71,7 \\
Friends & 27 & 24 & 95,7 \\
Family & 11 & 4,3 & 100,0 \\
Co-worker & 2 & & \\
Total & 46 & 100,0 & \\
\hline
\end{tabular}

Fig. 4 With which company have you seen the movie?

\begin{tabular}{|l|r|r|r|}
\hline & & Prequency & \multicolumn{2}{l|}{$\begin{array}{l}\text { Cumulative } \\
\text { Percent }\end{array}$} \\
& & & \\
& & & \\
\hline Partner & 3 & 6,5 & 6,5 \\
Friends & 12 & 26,1 & 32,6 \\
Family & 2 & 4,3 & 36,9 \\
Co-worker & 1 & 2,1 & 39 \\
Social Media & 28 & 61 & 100,0 \\
& & & \\
Total & 46 & 100,0 & \\
\hline
\end{tabular}

Fig. 5 Who had influenced you more? 
INTERNATIONAL JOURNAL OF ACADEMIC RESEARCH IN BUSINESS AND SOCIAL SCIENCES

Vol. 8, No. 10, Oct. 2018, E-ISSN: 2222-6990 @ 2018 HRMARS

\begin{tabular}{|l|r|r|c|}
\hline & Frequency & Percent & \multicolumn{2}{l|}{$\begin{array}{l}\text { Pumulative } \\
\text { Percent }\end{array}$} \\
\hline Less than 5€ & 2 & 4,3 & 4,3 \\
Between 5 -7 & 8 & 17,4 & 21,7 \\
Between 7-10€ & 36 & 78,3 & 100,0 \\
& & & \\
Total & 46 & 100,0 & \\
\hline
\end{tabular}

Fig. 6 How much did you pay for the ticket?

These three tables well represent the consumers' trend and taste now in Italy. It is evident how the free time is generally spent with friends and a partner accounting for more the $71,7 \%$ of the times. The suggestion or hint to see that movie was generally due to social media and friends influence and so it explains how the WOM and its eWOM are the main keys to attract people at the movie theater. Beside this the ticket price is very expensive if compared to China where almost the $78 \%$ of the moviegoers have spent between 7 and $10 €$ or 56 to 80 RMB per ticket. In fact the 3D movie has often a surcharge of price of $3 €$ that lead the normal price ticket to vary considerably. Considering instead the general habits of moviegoers in Italy :

\begin{tabular}{|l|r|r|c|}
\hline & Frequency & Percent & \multicolumn{2}{l|}{$\begin{array}{l}\text { Cumulative } \\
\text { Percent }\end{array}$} \\
\hline Less than 5 times & 12 & 26,1 & 26,1 \\
Between 5-10 & 21 & 45,6 & 71,7 \\
More than 10 & 14 & 30,3 & 100,0 \\
& 46 & & \\
Total & 400,0 & \\
\hline
\end{tabular}

Fig. 7 How often do you go to the cinema in a year?

\begin{tabular}{|c|c|c|c|}
\hline & Frequency & Percent & Cumulative Percent \\
\hline Partner & 11 & 24 & 24 \\
\hline Friends & 33 & 71,7 & 75,7 \\
\hline Family & 2 & 4,3 & 100,0 \\
\hline Total & 46 & 100,0 & \\
\hline
\end{tabular}

Fig. 8 Your favorite company to see a movie 
INTERNATIONAL JOURNAL OF ACADEMIC RESEARCH IN BUSINESS AND SOCIAL SCIENCES Vol. 8, No. 10, Oct. 2018, E-ISSN: 2222-6990 @ 2018 HRMARS

\begin{tabular}{|l|r|r|c|}
\hline & Frequency & Percent & Cumulative Percent \\
& & & \\
\hline Less than 5€ & 35 & 76 & 76 \\
Between 5-7€ & 11 & 24 & 100,0 \\
Total & 46 & 100,0 & \\
\hline
\end{tabular}

Fig. 9 How much do you wish to pay ?

About half of the respondents go to the cinema almost once every two months resulting so a good presence of movie fans in Italy. The $83 \%$ of them by the way like to enjoy and spent this time with their own friends and in a relationship "friend" while few of them with their family. Besides this the willing to pay less than $5 €$ is very desired maybe because of this economic crisis and the reduced budget among many Italian families. This explains also one key aspect of the demographic where most of the interviewees are students so they haven't a regular wage and maybe don't have much money to spend.

We have fatherly examined many other factors and specifically the degree of agreement to the following questions :

\begin{tabular}{|l|c|}
\hline & MEAN (1-9) \\
\hline In order to pay less for a film, I am ready to wait to watch it & 6,152 \\
\hline I prefer to see a film at home rather than at the cinema & 4.261 \\
\hline Readiness for pay through mobile APP & 7.109 \\
\hline $\begin{array}{l}\text { Possibility to choose the seats and the bundle offers in the } \\
\text { previous APP (eat/drink/gadget/nothing + movie ticket ) }\end{array}$ & 7.022 \\
\hline Readiness for pay through credit card & 5,196 \\
\hline
\end{tabular}

Fig. 10 The personal taste of Italian moviegoers

The previous table represents the answers to more specific questions related to personal taste when it comes to see a movie. Whether it is at the cinema or at home many Italians prefer to enjoy the movie at the cinema maybe due to its more immersive atmosphere and pleasure that come from it and they will is to wait as long as possible in order to get a discount to their ticket. In fact, in Italy in the week after the first release there is a day that has a general discount on the film that allow people to buy a ticket for just $5 €(40 \mathrm{RMB})$. While the price cannot be compared to the Chinese counterpart it is clear that it is on average higher and influence a bit on the purchasing intention. What is more amazing is the fact that many people believe that a modernization of this system could be beneficial. Indeed they will be very favorable to a swift to an electric ticket that is easily purchasable on their own smartphone. Furthermore if it is joined with special offers and bundles it will boost certainly their satisfaction. Added to the fact that more than $80 \%$ of Italians eat or drink some food at the movie theater this new implementation will change their willingness to 
INTERNATIONAL JOURNAL OF ACADEMIC RESEARCH IN BUSINESS AND SOCIAL SCIENCES

Vol. 8, No. 10, Oct. 2018, E-ISSN: 2222-6990 @ 2018 HRMARS

go more often to the cinema. The new system is prevalently preferred to the use of the credit card because of its more practicality and convenience.

\section{Conclusion}

In this paper it has been demonstrated that the Italian people in general spend much time on their devices and social media and are well informed about new coming movies. Many of them receive new inputs and hints about these movies generally from friends and social media which allow them to follow their beloved actors and movies. Furthermore through an empirical observation we have found that one of the causes to the Italian downward box office revenue is due to no new improvements on this system. We are aware that such a system have produced and favored the box office earnings in China and so this can also influence positively the Italian market where from one side the consumers believe that the price of the ticket is too high and on the other side they will encouraged from the adoption of this new system if it could facilitate and meet their needs. Furthermore, we have seen how the majority of people presents a strictly positive correlation between the two variables: Readiness for pay through mobile APP and Possibility to choose the seats and the bundle offers in the previous APP. In fact their Pearson correlation coefficient is almost near to 1 (0.94) implying that it is very useful and recommended to introduce such a new technology in Italy that will boost certainly the consumption.

If from one side the Italians prefer to see their movie at the cinema and not at home and on the other side the investors could meet their need and satisfy them through new bundle offers the attendance at the movie theater will increase. Also due to the economic crisis in which Italy is living nowadays the attention to customers' necessities is so an important factor to be taken into consideration if the Italian cinema wants to recover from this situation.

\section{References}

Barn, S. (2009). Product placement in Bollywood movies. Marketing Intelligence and Planning, 27(7), 976-980. https://doi.org/10.1108/02634500911000252

Chambers, J. W. (2006). The Movies and the Antiwar Debate in America, 1930-1941. Film \&amp; History: An Interdisciplinary Journal of Film and Television Studies, 36(1), 44-57. https://doi.org/10.1353/flm.2006.0001

DeBauche, L. M. (2009). Movies and practical patriotism. In American Cinema of the 1910s: Themes and variations (pp. 183-203). Retrieved from https://www.scopus.com/inward/record.uri?eid=2-s2.084904592718\&partnerID=40\&md5=38186f7e66ea0982d550d0f8882e7148

Denby, D. (2012). Has Hollywood Murdered the Movies? New Republic, 243(15), 29. Retrieved from http://search.ebscohost.com/login.aspx?direct=true\&db=f5h\&AN=79962000\&lang=hr\&site=e host-live

Dickinson, M., \& Harvey, S. (2005). Film policy in the United Kingdom: New Labour at the movies. The Political Quarterly, 76(3), 420-429. https://doi.org/10.1111/j.1467-923X.2005.00701.x

Dreyer, C. (1970). Color and Color Films. In The Movies As Medium (pp. 197-200).

Everett, W. (2009). Lost in transition ? The European road movie, or a genre "adrift in the cosmos." Literature/Film Quarterly, 37(3), 165-176. 
INTERNATIONAL JOURNAL OF ACADEMIC RESEARCH IN BUSINESS AND SOCIAL SCIENCES

Vol. 8, No. 10, Oct. 2018, E-ISSN: 2222-6990 ㄷ 2018 HRMARS

Mohsin, M., Rasheed, A. K., \& Saidur, R. (2018). Economic viability and production capacity of wind generated renewable hydrogen. International Journal of Hydrogen Energy. https://doi.org/10.1016/j.ijhydene.2017.12.113

Mohsin, M., Zhou, P., Iqbal, N., \& Shah, S. A. A. (2018). Assessing oil supply security of South Asia. Energy, 155, 438-447. https://doi.org/10.1016/J.ENERGY.2018.04.116

Obiaya, I. (2013). Taking Nigeria to the movies: The innovative regulatory role of the National Film and Video Censors Board. Journal of African Media Studies, 5(3), 261-274. https://doi.org/10.1386/jams.5.3.261_1

Orlov, D., \& Ozhegov, E. (2015). Estimating the Efficiency of Sequels in the Film Industry. SSRN. https://doi.org/10.2139/ssrn.2622493

Sargent, J. D., \& Hanewinkel, R. (2015). The Tobacco Epidemic. Progress in Respiratory Research, 42, 171-180. https://doi.org/10.1159/isbn.978-3-318-02657-3

Shim, D. (2011). Whither the Korean film industry? Acta Koreana, 14(1), 213-227.

Teti, E. (2013). The dark side of the movie. The difficult balance between risk and return. Management Decision, 51(4), 730-741. https://doi.org/10.1108/00251741311326536

The Association of European Vehicle Logistics. (2014). Vehicle logistics industry says it is time to prepare for an era of solid growth starting in 2015. ECG News, (Issue 14.20). Retrieved from http://www.ecgassociation.eu/Portals/0/Documentation/ECG News 2014/ECG News 14.20.pdf

Wasko, J. (1982). Movies and money: Financing the American film industry. Financing the American film industry. https://doi.org/10.1016/0304-8853(93)90697-Z

Zhao, W. (2017). A study on the framework of ideology and values in Hollywood movies from the big data perspective. Boletin Tecnico/Technical Bulletin, 55(10), 134-140. 